
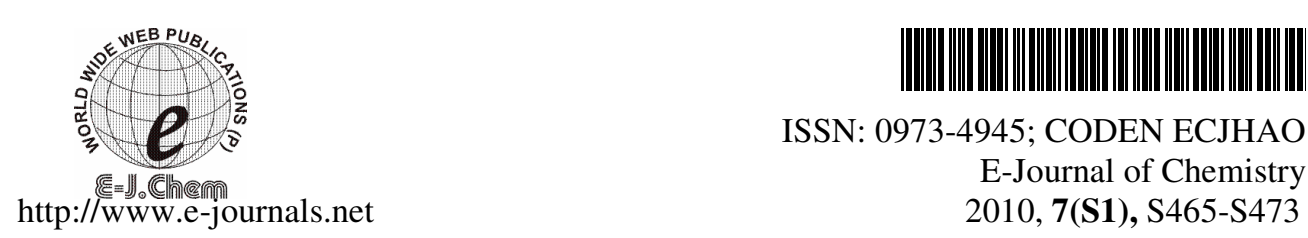

ISSN: 0973-4945; CODEN ECJHAO

E-Journal of Chemistry 2010, 7(S1), S465-S473

\title{
Seasonal Distribution of Trace Metals in Ground and Surface Water of Golaghat District, Assam, India
}

\author{
M. BOARH ${ }^{*}$ and A. K. MISRA \\ Department of Chemistry, Gauhati University, Guwahati-781014, India \\ madhabborah@yahoo.co.in
}

Received 8 February 2010; Accepted 20 April 2010

\begin{abstract}
A study has been carried out on the quality of ground and surface water with respect to chromium, manganese, zinc, copper, nickel, cadmium and arsenic contamination from 28 different sources in the predominantly rural Golaghat district of Assam (India). The metals were analysed by using atomic absorption spectrometer. Water samples were collected from groundwater and surface water during the dry and wet seasons of 2008 from the different sources in 28 locations (samples). The results are discussed in the light of possible health hazards from the metals in relation to their maximum permissible limits. The study shows the quality of ground and surface water in a sizeable number of water samples in the district not to be fully satisfactory with respect to presence of the metals beyond permissible limits of WHO. The metal concentration of groundwater in the district follows the trend As $>\mathrm{Zn}>\mathrm{Mn}>\mathrm{Cr}>\mathrm{Cu}>\mathrm{Ni}>\mathrm{Cd}$ in both the seasons.
\end{abstract}

Keywords: Trace metals, Groundwater, Surface water, Assam.

\section{Introduction}

Groundwater has been used as a source of drinking water for millions of rural and urban families in India. Heavy metal contamination of groundwater more often than not goes unnoticed and remains hidden from the public view. Presently, it has raised wide spread concerns in different parts of the world and results reported by various agencies have been alarming ${ }^{1-2}$. The concentration of toxic metal ions has increased beyond environmentally and ecologically sustainable levels due to natural phenomenon as well as anthropogenic impact. The poisoning effect of toxic metals from contaminated drinking water has evolved as one of the major health hazards in the 21 st century $^{3,4}$. There is also evidence of prevailing heavy metal contamination of groundwater in many areas of India ${ }^{5,6}$. Recent studies show that the levels of trace metals present in drinking water could seriously affect human health ${ }^{7-11}$.In the third world countries, the common people and sometimes even in the highly educated 
people are not aware of the dangers of contamination of drinking water sources. Therefore, it is utmost importance to determine the quality of drinking water with respect to all constituents and take proper remedial measures, if required, to ensure quality criteria as formulated by $\mathrm{WHO}$ and other regulating bodies ${ }^{12}$. Of all the contaminants present in water, metals are very important in governing drinking water quality. The presence of some metals in drinking water is desirable to certain extents for proper maintenance of human health. Above these limits, they behave as pollutants and toxicants causing serious health hazards. Again, some metals should not be present in water even in trace amounts because of their high degree of toxicity.

The present study area lies between $93^{\circ} 49^{\prime} 8^{\prime \prime}$ to $94^{\circ} 12^{\prime} 22^{\prime \prime} \mathrm{N}$ and $26^{\circ} 41^{\prime} 15^{\prime \prime}$ to $26^{\circ} 5^{\prime} \mathrm{E}$.It is the Golaghat subdivision of northeast part of Golaghat district (source: office of deputy director, economics and statistics, Golaghat district). The Golaghat sub-division having an area of 1838 $\mathrm{km}^{2}$ has total population of 591924, as per 2001 census (Source: Office of deputy director, economics and statistics, golaghat district).The most widely used sources of drinking water in the Golaghat district are ring well and tube wells and sometimes pond water and river water also. The urban water supply scheme is inadequate and supply water only in some locations in Golaghat town. A large section of the people even in urban areas has to depend on tube wells and ring wells for their water needs and in the areas, these are the only sources for the people. The objective of the present work is to study the quality of ground and surface water in the district with respect to a few important metals $\mathrm{Cr}, \mathrm{Mn}, \mathrm{Fe}, \mathrm{Co}, \mathrm{Ni}, \mathrm{Cu}, \mathrm{Zn}, \mathrm{Pb}$ and $\mathrm{As}$.

\section{Experimental}

After thorough study of the topographic and climatic conditions of the study area, it was decided to collect twenty eight ground and surface water samples from tube wells, ring wells, rivers, pond and lake and supply water from Golaghat sub-division of Golaghat district during dry and wet season of 2008. The sampling stations, the type of sources, $\mathrm{Cr}, \mathrm{Mn}, \mathrm{Fe}, \mathrm{Co}, \mathrm{Ni}$, $\mathrm{Cu}, \mathrm{Zn}$ and $\mathrm{Pb}$ and As concentrations (ppm) for both dry and wet seasons are listed in Table 1 . The water samples were collected in pre-cleaned plastic containers of $5 \mathrm{~L}$ capacity. The samples were preheated and reserved properly and analysis for heavy metals was carried out following standard procedure (APHA, 1995). To determine the amount of metals, $100 \mathrm{~mL}$ of each sample was acidified with conc. $\mathrm{HNO}_{3}$ and was then allowed to evaporate in an oven at temperature $60-50{ }^{\circ} \mathrm{C}$ for reducing the volume to $20-30 \mathrm{~mL}$. Then volume was made up to $100 \mathrm{~mL}$ by the addition of doubled distilled water. Finally the resulting samples were then analyzed using atomic absorption spectrophotometer (Variant spectra AA220).

\section{Results and Discussion}

Water sampling locations and sources are presented in Table 1. The experimental results are presented in Table 2. To look into the seasonal variations and distribution patterns of the metal contents in groundwater, data were exposed to several statistical treatments. Descriptive statistics based on normal distribution has been summarised for both dry and wet season in Table $3 \& 4$ respectively. Seasonal distributions of various metals in groundwater are graphically presented in Figures 1-7.

In the present study chromium content in groundwater are found to be above the permissible limit (in dry season) of WHO with a mean value of $0.0612 \mathrm{ppm}$ and $0.04386 \mathrm{ppm}$ respectively in dry and wet season. It may be seen from Table II that some of the water samples contain chromium at toxic levels. The skewness and kurtosis values for chromium in both the seasons indicate that its distribution in the study area is not uniform. 
Table 1. Water sampling locations and sources

\begin{tabular}{cccccc}
\hline S. No & Sampling stations & Source & S. No & Sampling stations & Source \\
\hline TW1 & Mission patty, Golaghat & Tube well & RW1 & Kamarbandha & Ring well \\
TW2 & Errangapara, Golaghat & Tube well & RW2 & Merapani & Ring well \\
TW3 & Tatalital, Golaghat & Tube well & RW3 & Sagunpara, Golaghat & Ring well \\
TW4 & Sagunpara, Golaghat & Tube well & RW4 & Jamuguri, Golaghat & Ring well \\
TW5 & Jamuguri, Golaghat & Tube well & RW5 & Pulibor, Golaghat & Ring well \\
TW6 & Puspaban, Golaghat & Tube well & RIW1 & Dhansiri, Golaghat & River water \\
TW7 & Fatual, Furkating & Tube well & RIW2 & Doyang & River water \\
TW8 & Ghilaghary H.S. School & Tube well & RIW3 & Rangma & River water \\
TW9 & Bahbari & Tube well & RIW4 & Kakodonga & River water \\
TW10 & Athkhelia & Tube well & RIW5 & Nambor & River water \\
TW11 & Dhekial & Tube well & RIW6 & Doigrong & River water \\
TW12 & Silonijan & Tube well & PW & Tenpur pond & Pond water \\
TW13 & Purabangla & Tube well & LW & Sankar lake & Lake water \\
TW14 & Latakujan tea estate & Tube well & SW & Golaghat Town & Supply water \\
\hline
\end{tabular}

Table 2. Metal content in ground and surface water of Golaghat district at 20 different stations

\begin{tabular}{|c|c|c|c|c|c|c|c|c|}
\hline \multirow{2}{*}{$\begin{array}{c}\text { Sample } \\
\text { No. }\end{array}$} & \multirow{2}{*}{ Season } & $\mathrm{Cr}$ & $\mathrm{Mn}$ & $\mathrm{Zn}$ & $\mathrm{Cu}$ & $\mathrm{Ni}$ & $\mathrm{Cd}$ & As \\
\hline & & in $\mathrm{ppm}$ & in $\mathrm{ppm}$ & in $\mathrm{ppm}$ & in ppm & in ppm & in $\mathrm{ppm}$ & in $\mathrm{ppb}$ \\
\hline \multirow{2}{*}{ TW1 } & Dry & 0.022 & 0.206 & 0.886 & 0.026 & 0.020 & 0.003 & 8 \\
\hline & Wet & BDL & 0.194 & 0.775 & 0.031 & 0.019 & BDL & 5 \\
\hline \multirow{2}{*}{ TW2 } & Dry & 0.117 & 0.117 & 0.624 & 0.024 & 0.022 & 0.002 & 38 \\
\hline & Wet & 0.112 & 0.112 & 0.534 & 0.035 & BDL & BDL & 12 \\
\hline \multirow{2}{*}{ TW3 } & Dry & 0.125 & 0.119 & 0.622 & 0.023 & 0.028 & 0.012 & 16 \\
\hline & Wet & 0.134 & 0.104 & 0.586 & 0.033 & 0.018 & BDL & 12 \\
\hline \multirow{2}{*}{ TW4 } & Dry & 0.021 & 0.125 & 1.122 & BDL & 0.025 & 0.005 & 7 \\
\hline & Wet & BDL & 0.091 & 0.962 & 0.021 & 0.022 & 0.002 & 3 \\
\hline \multirow{2}{*}{ TW5 } & Dry & 0.098 & 0.134 & 1.144 & 0.322 & 0.036 & BDL & 9 \\
\hline & Wet & 0.113 & 0.095 & 0.966 & 0.122 & 0.022 & BDL & 4 \\
\hline \multirow{2}{*}{ TW6 } & Dry & 0.120 & 0.114 & 0.675 & 0.031 & 0.026 & BDL & 9 \\
\hline & Wet & 0.040 & 0.083 & 0.314 & BDL & 0.013 & BDL & 7 \\
\hline \multirow{2}{*}{ TW7 } & Dry & 0.122 & 0.013 & 1.065 & 0.221 & 0.018 & 0.003 & 202 \\
\hline & Wet & 0.076 & 0.006 & 0.752 & 0.128 & 0.028 & 0.004 & 164 \\
\hline \multirow{2}{*}{ TW8 } & Dry & 0.032 & 0.114 & 1.175 & 0.032 & 0.018 & BDL & 26 \\
\hline & Wet & BDL & 0.088 & 0.878 & 0.024 & BDL & BDL & 14 \\
\hline \multirow{2}{*}{ TW9 } & Dry & 0.028 & 0.211 & 0.222 & 0.034 & 0.031 & 0.007 & 200 \\
\hline & Wet & 0.041 & 0.162 & 0.144 & 0.021 & 0.024 & 0.004 & 162 \\
\hline \multirow{2}{*}{ TW10 } & Dry & 0.032 & 0.151 & 1.123 & 0.036 & 0.016 & BDL & 192 \\
\hline & Wet & BDL & 0.123 & 1.077 & 0.017 & 0.024 & BDL & 162 \\
\hline \multirow{2}{*}{ TW11 } & Dry & 0.130 & 0.211 & 1.534 & 0.008 & 0.032 & 0.002 & 22 \\
\hline & Wet & 0.077 & 0.124 & 0.988 & 0.024 & 0.022 & BDL & 18 \\
\hline \multirow[t]{2}{*}{ TW12 } & Dry & 0.211 & 0.084 & 1.087 & 0.017 & BDL & BDL & 22 \\
\hline & Wet & 0.163 & 0.073 & 0.843 & 0.012 & 0.011 & BDL & 18 \\
\hline \multirow{2}{*}{ TW13 } & Dry & 0.014 & 0.063 & 0.843 & 0.028 & 0.024 & 0.003 & 9 \\
\hline & Wet & BDL & 0.043 & 0.655 & 0.021 & 0.024 & 0.002 & $\begin{array}{c}6 \\
\text { Contd... }\end{array}$ \\
\hline
\end{tabular}




\begin{tabular}{|c|c|c|c|c|c|c|c|c|}
\hline \multirow{2}{*}{ TW14 } & Dry & BDL & 0.172 & 0.746 & 0.018 & 0.025 & BDL & 8 \\
\hline & Wet & BDL & 0.115 & 0.462 & 0.015 & 0.017 & BDL & 7 \\
\hline \multirow{2}{*}{ RW1 } & Dry & 0.102 & 0.213 & 0.634 & 0.041 & 0.018 & 0.004 & 35 \\
\hline & Wet & 0.100 & 0.085 & 0.248 & 0.012 & 0.015 & 0.002 & 8 \\
\hline \multirow{2}{*}{ RW2 } & Dry & 0.028 & 0.089 & 0.988 & 0.016 & 0.018 & 0.012 & 36 \\
\hline & Wet & BDL & 0.089 & 0.655 & 0.012 & 0.029 & 0.002 & 24 \\
\hline \multirow{2}{*}{ RW3 } & Dry & 0.016 & 0.093 & 1.122 & 0.047 & 0.024 & 0.003 & 9 \\
\hline & Wet & 0.023 & 0.063 & 0.938 & 0.017 & BDL & 0.007 & 6 \\
\hline \multirow{2}{*}{ RW4 } & Dry & 0.162 & 0.085 & 0.845 & 0.046 & 0.062 & 0.36 & 8 \\
\hline & Wet & 0.184 & 0.075 & 0.948 & 0.035 & 0.028 & 0.36 & 4 \\
\hline \multirow{2}{*}{ RW5 } & Dry & 0.117 & 1.023 & 1.787 & 0.032 & 0.045 & 0.004 & 153 \\
\hline & Wet & 0.115 & 0.462 & 1.132 & 0.017 & 0.016 & 0.004 & 102 \\
\hline \multirow{2}{*}{ RIW1 } & Dry & 0.012 & 0.068 & 0.574 & BDL & 0.028 & 0.015 & 12 \\
\hline & Wet & 0.004 & 0.034 & 0.438 & 0.026 & 0.014 & 0.011 & 8 \\
\hline \multirow{2}{*}{ RIW2 } & Dry & 0.011 & 0.077 & 1.642 & 0.022 & 0.037 & 0.021 & 8 \\
\hline & Wet & 0.006 & 0.037 & 0.849 & 0.021 & 0.038 & 0.015 & 11 \\
\hline \multirow{2}{*}{ RIW3 } & Dry & 0.011 & 0.102 & 1.322 & 0.014 & 0.024 & BDL & 9 \\
\hline & Wet & BDL & 0.042 & 0.676 & BDL & BDL & BDL & 5 \\
\hline \multirow{2}{*}{ RIW4 } & Dry & 0.015 & 0.094 & 0.865 & 0.022 & 0.024 & 0.004 & 6 \\
\hline & Wet & BDL & 0.046 & 0.434 & 0.012 & 0.022 & 0.002 & 3 \\
\hline \multirow{2}{*}{ RIW5 } & Dry & 0.017 & 0.077 & 1.246 & 0.022 & 0.018 & BDL & 3 \\
\hline & Wet & 0.006 & 0.046 & 0.574 & 0.011 & BDL & BDL & BDL \\
\hline \multirow{2}{*}{ RIW6 } & Dry & 0.022 & 0.034 & 1.023 & 0.026 & BDL & 0.003 & BDL \\
\hline & Wet & BDL & 0.072 & 0.324 & 0.018 & BDL & BDL & BDL \\
\hline \multirow{2}{*}{ PW } & Dry & 0.056 & 0.096 & 1.034 & 0.014 & 0.028 & BDL & 9 \\
\hline & Wet & 0.016 & 0.082 & 0.764 & BDL & BDL & BDL & BDL \\
\hline \multirow{2}{*}{ LW } & Dry & 0.058 & 0.26 & 1.442 & 0.015 & 0.022 & 0.014 & 2 \\
\hline & Wet & 0.018 & 0.112 & 0.798 & 0.014 & BDL & BDL & 2 \\
\hline \multirow{2}{*}{ SW } & Dry & 0.016 & 0.093 & 1.027 & 0.027 & BDL & 0.001 & 7 \\
\hline & Wet & BDL & 0.071 & 0.964 & 0.013 & 0.024 & BDL & 6 \\
\hline
\end{tabular}

Table 3. Comparison of statistical data of different metals in dry season

\begin{tabular}{lccccccc}
\hline \multicolumn{1}{c}{ Statistics } & $\mathrm{Cr}$ & $\mathrm{Mn}$ & $\mathrm{Zn}$ & $\mathrm{Cu}$ & $\mathrm{Ni}$ & $\mathrm{Cd}$ & $\mathrm{As}$ \\
\hline Minimum & $\mathrm{BDL}$ & 0.034 & 0.222 & $\mathrm{BDL}$ & $\mathrm{BDL}$ & $\mathrm{BDL}$ & $\mathrm{BDL}$ \\
Maximum & 0.221 & 0.113 & 1.787 & 0.322 & 0.062 & 0.36 & 202 \\
Mean & 0.0612 & 0.1513 & 1.0149 & 0.04157 & 0.02389 & 0.01707 & 38.03571 \\
Standard & 0.0105 & 0.0334 & 0.0642 & 0.0125 & 0.00234 & 0.0125 & 11.7082 \\
error & & & & & & & \\
Median & 0.03 & 0.108 & 0.781 & 0.025 & 0.024 & 0.003 & 9 \\
mode & 0.011 & 0.077 & 0.655 & 0.022 & 0.018 & 0.000 & 9 \\
Standard & 0.05607 & 0.1771 & 0.3399 & 0.0661 & 0.0124 & 0.0662 & 61.9524 \\
deviation & & & & & & & \\
Variance & 0.0031 & 0.0055 & 0.1155 & 0.0043 & 0.00015 & 0.0043 & 3838.0998 \\
Coefficient & 0.916 & 1.170 & 0.3349 & 1.590 & 0.5190 & 3.8781 & 1.6287 \\
of variance & & & & & & & \\
Skewness & 7.4833 & 1.6385 & 0.136312 & 7.5498 & 5.46156 & 0.00000 & 5.68035 \\
Kurtosis & 56.0000 & 0.90678 & 0.344704 & 57.0000 & 29.7752 & -3.16767 & 34.8610 \\
Range & 0.221 & 0.079 & 1.565 & 0.322 & 0.062 & 0.36 & 202 \\
sum & 1.7149 & 4.2379 & 28.4189 & 1.1640 & 0.6690 & 0.4780 & 1065 \\
\hline
\end{tabular}


Table 4. Comparison of statistical data of different metals in wet season

\begin{tabular}{lccccccc}
\hline Statistics & $\mathrm{Cr}$ & $\mathrm{Mn}$ & $\mathrm{Zn}$ & $\mathrm{Cu}$ & $\mathrm{Ni}$ & $\mathrm{Cd}$ & $\mathrm{As}$ \\
\hline Minimum & $\mathrm{BDL}$ & $\mathrm{BDL}$ & 0.144 & $\mathrm{BDL}$ & $\mathrm{BDL}$ & $\mathrm{BDL}$ & $\mathrm{BDL}$ \\
Maximum & 0.184 & 0.184 & 1.132 & 0.128 & 0.038 & 0.36 & 164 \\
Mean & 0.04386 & 0.09746 & 0.70279 & 0.02543 & 0.01536 & 0.01482 & 27.60714 \\
Standard error & 0.01066 & 0.82290 & 0.04917 & 0.005501 & 0.002090 & 0.0125 & 9.49722 \\
Median & 0.011 & 0.084 & 0.758 & 0.0175 & 0.0175 & 0 & 7 \\
mode & 0.000 & 0.046 & 0.655 & 0.012 & 0 & 0 & 0 \\
Standard & 0.05645 & 0.0802 & 0.2602 & 0.02911 & 0.01106 & 0.06652 & 50.25459 \\
deviation & & 0.0064 & 0.0677 & 0.00084 & 0.000121 & 0.00442 & 2525.52 \\
Variance & 0.0031 & 0.025 & \\
Coefficient & 1.2870 & 0.8234 & 0.3702 & 1.1447 & 0.72005 & 4.48852 & 1.82034 \\
of variance & & & & & & & \\
Skewness & 1.10861 & 0.00000 & 5.29150 & 0.00000 & -0.19653 & 5.26768 & 2.25124 \\
Kurtosis & -0.04424 & -3.3646 & 28.0000 & -3.35042 & -1.00196 & 27.82308 & 3.61477 \\
Range & 0.184 & 0.184 & 0.988 & 0.128 & 0.038 & 0.36 & 164 \\
sum & 1.228 & 2.7289 & 19.6780 & 0.7120 & 0.4300 & 0.4150 & 773 \\
\hline
\end{tabular}

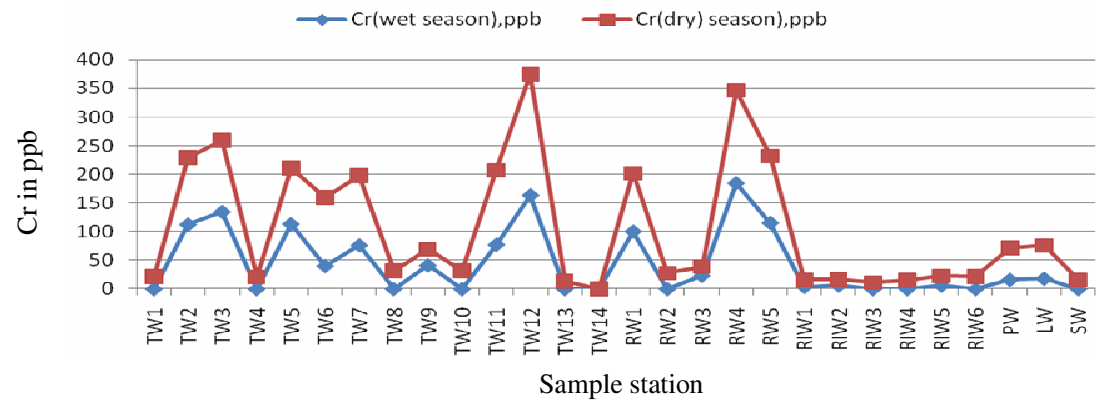

Figure 1. Seasonal variations of $\mathrm{Cr}(\mathrm{ppb})$ in the study area

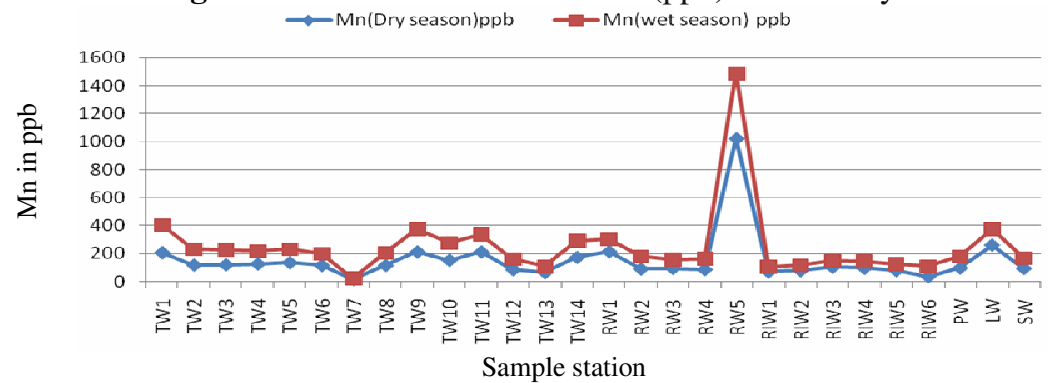

Figure 2. Seasonal variations of $\mathrm{Mn}(\mathrm{ppb})$ in the study area

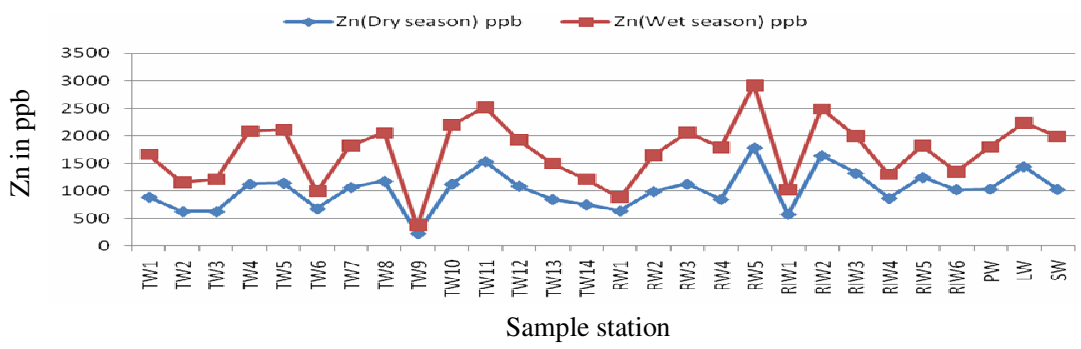

Figure 3. Seasonal variations of $\mathrm{Zn}(\mathrm{ppb})$ in the study area 


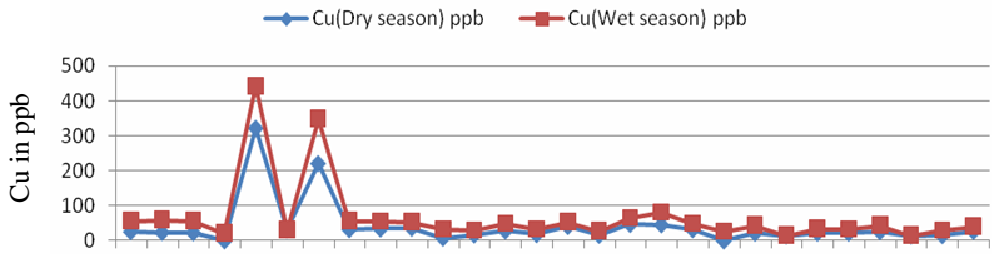

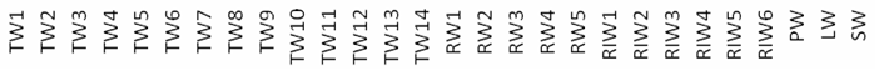

Sample station

Figure 4. Seasonal variations of $\mathrm{Cu}(\mathrm{ppb})$ in the study area

$\rightarrow \mathrm{Ni}($ Dry season) ppb $\rightarrow-\mathrm{Ni}$ (Dry season) ppb

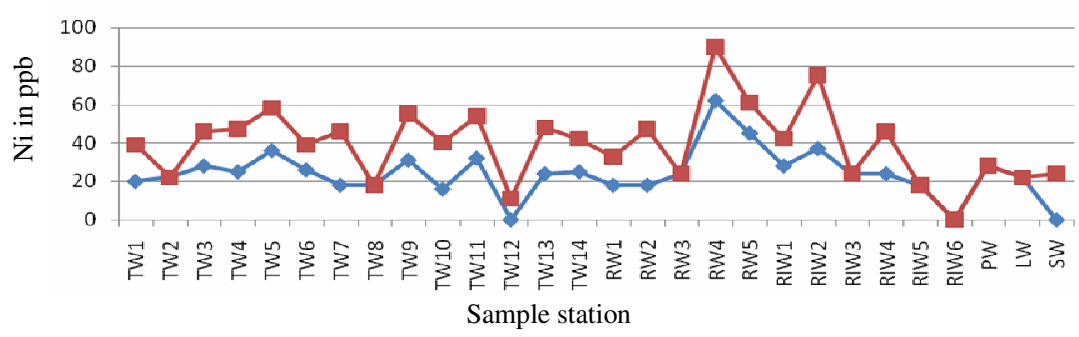

Figure 5. Seasonal variations of $\mathrm{Ni}(\mathrm{ppb})$ in the study area

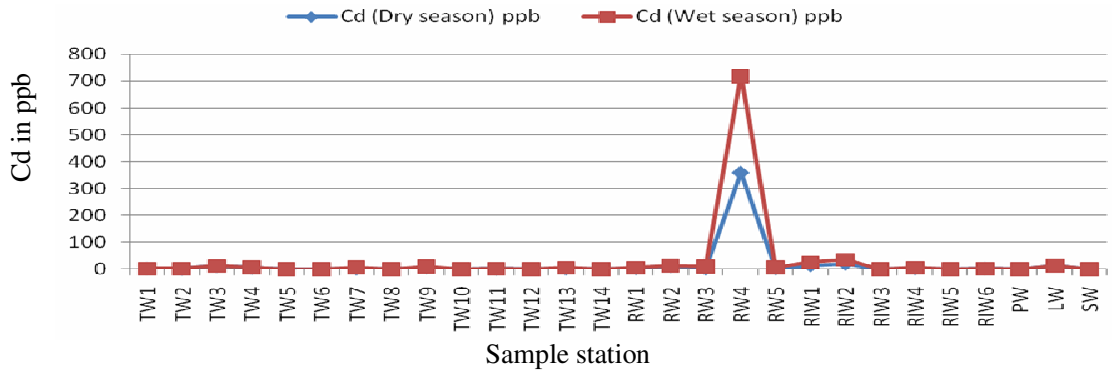

Figure 6. Seasonal variations of $\mathrm{Cd}(\mathrm{ppb})$ in the study area

$\multimap$ As (Dry season) ppb $\rightarrow$ As (Wet season) ppb

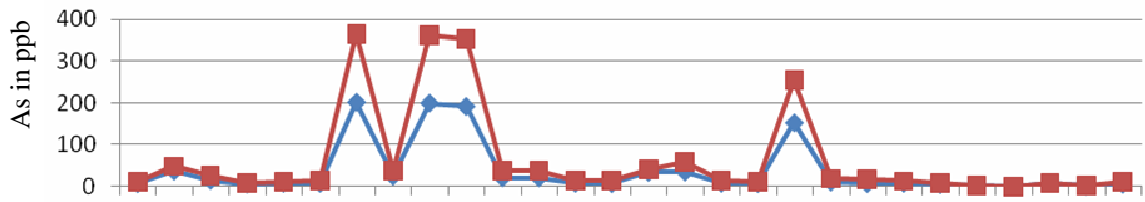

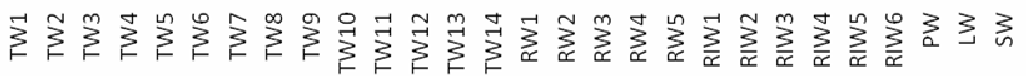

Sample station

Figure 7. Seasonal variations of As (ppb) in the study area

Manganese concentration in groundwater was found to be within the range of 0.034-0.113 ppm during dry season and BDL-0.184 ppm during wet season. It is seen from Table 2 and 3 that mean manganese contents exceed the permissible level of $0.1 \mathrm{ppm}$ $(\mathrm{WHO}, 2004)^{13}$ in $53.5 \%$ sampling points in dry season and $32.1 \%$ in wet season. Significant Standard deviations in case of manganese in dry season and wet season are likely to bias the normal distribution statistic. 
Manganese is a vital micronutrient for both plant and animals. It is found in various salts and minerals, frequently in association with iron compounds. The concentration of zinc in sampling sources is in the range of 0.222-1.787 in dry season and 0.144-1.132 in wet season. Zinc is a nutritionally essential element. It is necessary for growth and is involved in several physiological functions. In all the samples under investigation, the zinc contents are much below the guideline value of $3 \mathrm{ppm}$. Positive kurtosis and skewness value for zinc in both dry and wet season is indicative of its sharp asymmetric distribution with a long right tail from its median.

It has been found that copper levels are low with few of samples being below detection limits. Where the metal concentrations are above detection limits, they still fall below the WHO guidelines value of $1 \mathrm{ppm}$. Copper is an essential micronutrient, but in high concentration causes physiological effects in human. Water containing $3 \mathrm{mg}$ copper/L was associated with gastrointestinal disturbance in adults, whereas water containing $1 \mathrm{mg} / \mathrm{L}$ was not $^{14}$. Copper shows higher concentration during dry season. Positive kurtosis and skewness value for copper in dry season is indicative of its sharp asymmetric distribution with a long right tail from its median. Again in wet season the distribution (negative kurtosis) of data are platykurtic (lower peak than a normal distribution) having no longer tail with symmetrical distribution (zero skewness).

It has been observed that nickel content of some of the sampling sites is high with compared to WHO guideline value $0.02 \mathrm{mg} / \mathrm{L}$. Average nickel contents in dry season fall outside the maximum permissible limit of $0.02 \mathrm{ppm}$ as set by WHO whereas the average $\mathrm{Ni}$ contents in wet season fall below permissible limit of WHO. The maximum value is obtained at sampling point RW4 during dry season. Positive kurtosis and skewness value for nickel in dry season is indicative of its sharp asymmetric distribution with a long right tail from its median. Again in wet season the distribution is negatively skewed with a tail in negative direction and platykurtic with a lower peak than a normal distribution.

It has been observed that the average cadmium content in dry season is 0.01707 and in wet season 0.01482 whereas WHO guideline value is $0.005 \mathrm{ppm}$ and ISI limit is $0.01 \mathrm{ppm}$. So average cadmium contents in both dry and wet season fall outside the maximum permissible limit of ISI and fall below the permissible limit of WHO. The maximum cadmium content was found in RW4 $(0.36 \mathrm{ppm})$ in both dry and wet season. In dry season the distribution of data is negatively skewed with a tail in negative direction and platykurtic with a lower peak than a normal distribution. Positive kurtosis and skewness value for cadmium in wet season is indicative of its sharp asymmetric distribution with a long right tail from its median. Cadmium is not biodegradable, can accumulate in human vital organs, producing progressive toxicity. Source of occurrence (naturally) is the type soil.

Arsenic concentration in groundwater and surface was found to be within the range of BDL$202 \mathrm{ppb}$ during dry season and BDL-164 ppb during wet season. It is observed that groundwater samples of Golaghat district fall under alert category with respect to arsenic as some of the samples exceed and some are approaching the WHO (2004) and USEPA (2001) guideline value $10 \mathrm{ppb}$ (Table 2). Positive kurtosis and skewness value for arsenic in both the season is indicative of its sharp asymmetric distribution with a long right tail from its median. Wide data range and high standard deviation in case of arsenic in both dry and wet season are likely to bias the normal distribution statistic. Significant differences among mean, median and mode along with significant skewness and kurtosis values observed for arsenic in both the seasons are indicative of 
departure of sample frequency distribution curve from normal. Mean arsenic contents exceeds the permissible level of $10 \mathrm{ppb}$ (WHO, 2004) ${ }^{13}$ in $42.8 \%$ sampling points in dry season and $39.2 \%$ in wet season. The highest arsenic content was found in TW7 (202 ppb). So people should not drink water from this tube well.

During the study, seasonal variations are also observed for all the trace metals under investigation. By comparing the average values of all the trace metals, it is observed that the metal content of groundwater and surface in the district follows the trend $\mathrm{As}>\mathrm{Zn}>\mathrm{Mn}>\mathrm{Cr}>\mathrm{Cu}>\mathrm{Ni}>\mathrm{Cd}$ in both the seasons. It has been noticed that average arsenic concentrations in both the season fall in high alert category. Although, arsenic contents beyond the guideline value $(10 \mathrm{ppb})$ of WHO and USEPA have been found in a large number of samples, no report of Arsenocosis from the areas has been known till date.

\section{Conclusion}

Statistical observations on chromium, manganese, zinc, copper and nickel in ground and surface waters of Golaghat district, Assam show that all these metals exhibit a non-uniform distribution.

Comparing the water content of trace metals with the recommended maximum values for drinking purposes, it is found that a sizeable number of ground and surface samples contain chromium, manganese, nickel, cadmium and arsenic at an alert level. The concentrations of copper and zinc in the groundwater of the area are either low or moderate and within the guideline values of WHO.

Keeping in view of the unusually high concentrations of the harmful metals specially for arsenic at some of the sampling sites, it is concluded that regular monitoring of water sources should be ensured by the concerned authorities to prevent the outbreak of water borne diseases in the area.

\section{Acknowledgments}

The senior author acknowledges the assistance of the NEIST, Jorhat, in analysis of the water samples with ASS. Author is also grateful to Dr. K.G. Bhattacharjee for giving the opportunity to test the samples with ASS. The author is remaining thankful to the Rural Water Testing Laboratory conducted by Pragjyotika, Titabor, and Jorhat. The author is also thankful to PHE Department (Golaghat Division) of Golaghat district for providing important data for this work. The author also thanks his friends and seniors who help him during the course of this study.

\section{References}

1. Friberg L, Nordberg G F and Vouk V B, Ed., Handbook of the Toxicology of Metals, Elsevier, Amsterdam, 1986, 2, 130-184.

2. WHO/UNEP G E M S, Global Fresh Water Quality; Published on Behalf of the World Health Organization/United Nations Environment Programme, Oxford, Blackwell Reference, 1989.

3. Bagla P and Kaiser J, Science, 1996, 274, 174-175.

4. Lepkowski W, Arsenic Crisis in Bangladesh, C\&EN News, 1998, 27, November 16.

5. Sharma A, Sharma D K, Jangir J P and Gupta C M, Indian J Environ Protect, 1989, 9(4), 294-296.

6. Bhattacharya P, Chatterjee D and Jacks G, Water Resources Development, 1997, 13, 79-92. 
7. Chi-Man L and Jiu J J, Water Res., 2006, 40(4), 753-767.

8. Demirel Z, Environ Monit Assess., 2007, 132 (1-3), 15-23.

9. Nganje N, Edet A E and Ekwere S J, Environmental Geosciences (DEG), 2007, 14(1), 15- 29.

10. Yasuhiro S, Duong V T, Daigo S, Doan C and Yoshito K, J Health Sci., 2007, 53,.344-346.

11. Dixit R C, Varma S R, Notnaware V and Thacker N P, Indian J Environ Health, 2004, 45(2), 107-112.

12. Sarma B C, Misra A K and Bhattacharyya K G, Indian J Environ Protect., 2000, 21(4), 316-322.

13. WHO, Guidelines for Drinking water Quality, $3^{\text {rd }}$ Edition. Geneva: World Health Organization, 2004.

14. Pizarro F, Olivares M, Uauy R, Contreras P, Rebelo A and Gidi V, Environ Health Perspectives, 1999, 107, 117-121. 


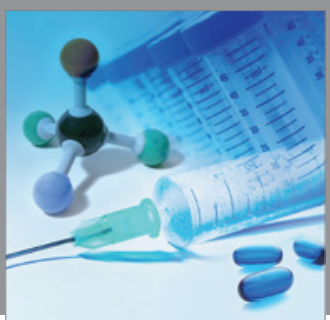

International Journal of

Medicinal Chemistry

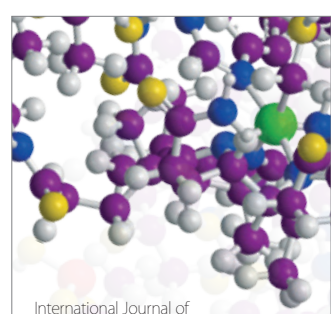

Carbohydrate Chemistry

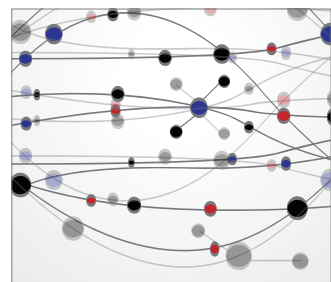

The Scientific World Journal
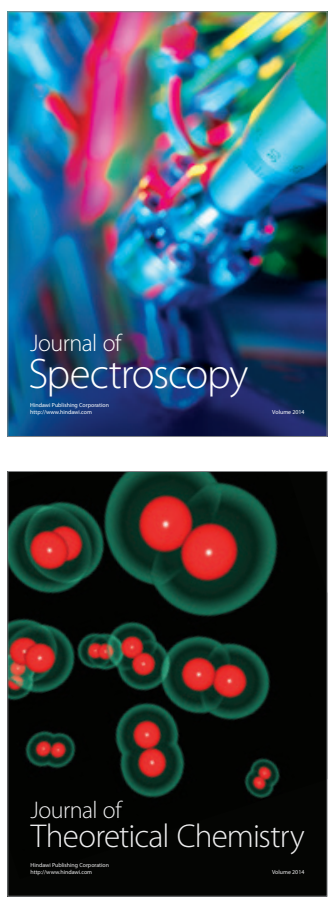
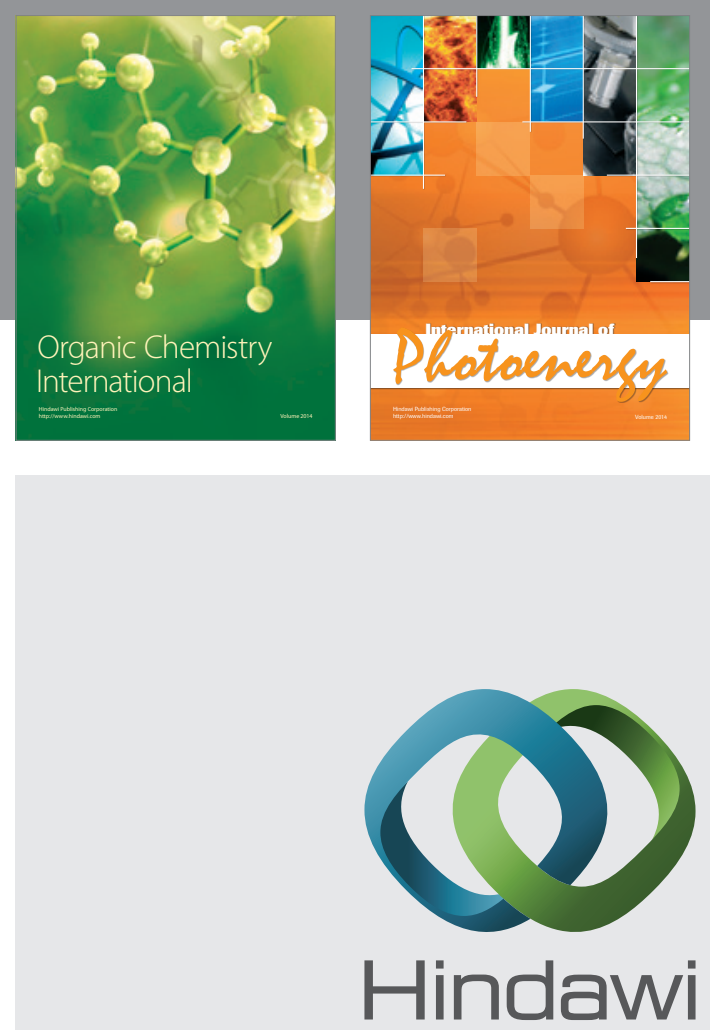

Submit your manuscripts at

http://www.hindawi.com
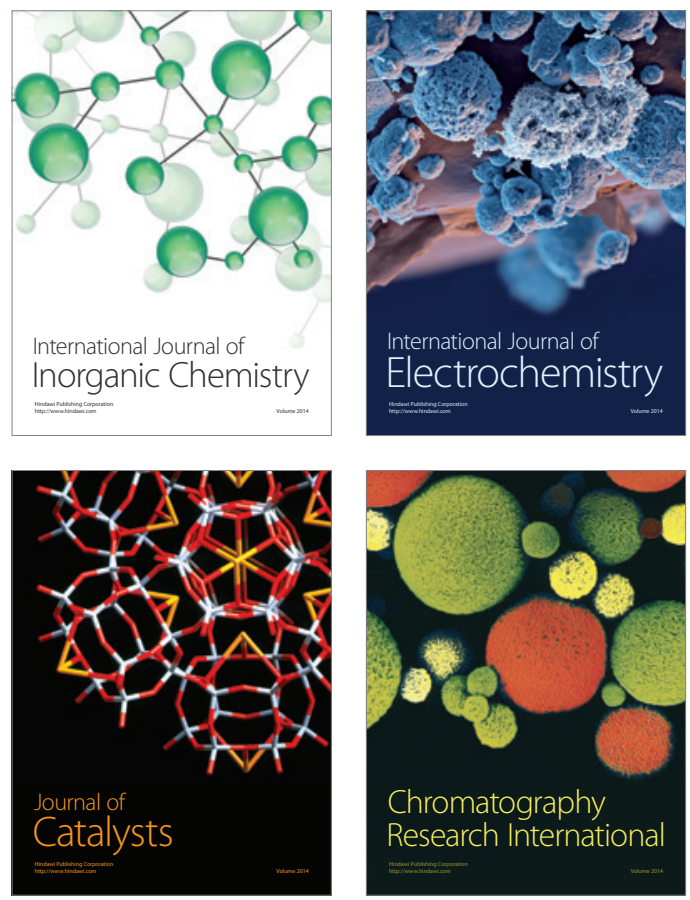
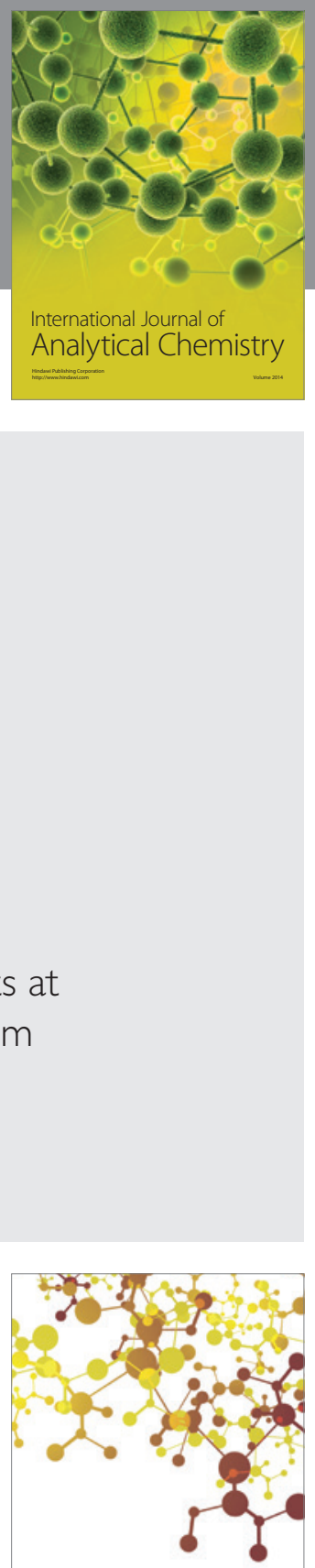

Journal of

Applied Chemistry
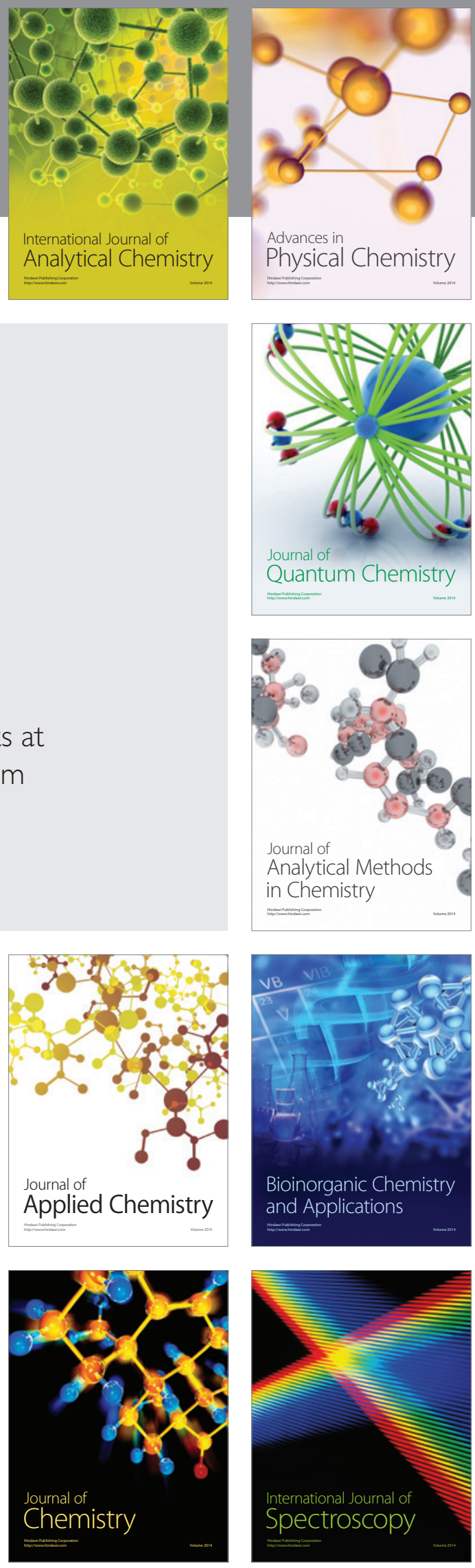